\title{
DOI 10.26886/2520-7474.2(28)2018.8
}

\section{UDC: 159.922 .7}

\section{THEORETICAL BASIS OF PERSONAL DIGNITY DEVELOPMENT}

\section{O. Shvets}

Drohobych Ivan Franko State Pedagogical University, Ukraine, Drohobych

The topicality of scientific psychological research of personality development is defined by the dynamics of worldview and value principles of modern society. The potential ability to develop with necessity is connected with such maxim as dignity. Dignity of a person is unconditional value based on their human nature. Dignity is considered the most important characteristics of person's living, complex integrative personal formation which is connected with self-development and gradual achievement of the results in social sphere as well as in personal and spiritual development.

Key words: development, personality, dignity, moral development, theories of development.

Швець О. М. Теоретичні засади розвитку гідності особистості/ Дрогобицький педагогічний університет імені Івана Франка, Україна, Дрогобич.

Динаміка світоглядних і ціннісних засад сучасного суспільства визначає актуальність науково-психологічних досліджень проблеми розвитку особистості. Потенційна спроможність до розвитку особистості з необхідністю пов'язана з такою максимою як гідність. Людська гідність - безумовна иінність людини на основі її людської природи. Гідність розәлядається найважливішим параметром життєдіяльності людини; складним інтегративним особистісним утворенням, що пов'язане із саморозвитком людини і послідовним 
досягненням нею результатів як у соціальній сорері, так $і$ зоні особистісного і духовного зростання.

Ключові слова: розвиток, особистість, гідність, моральний розвиток, теорії розвитку.

Постановка антроподетермінованих

проблеми.

Глобальна

динаміка ціннісних засад суспільства визначають дослідницькі пріоритети наукових розвідок у різних галузях. Актуальність психологічних досліджень, загострюється особливо, оскільки культурно-історична динаміка суспільства, еволюція цивілізації пов'язана із людиною. Історичний досвід переконує що для кризових періодів характерним $\epsilon$ пробудження та активізація антропологічної уяви і мотивації до зміни на основі удосконалення та посилення власної природи Людини. Не можна не погодитися із твердженням С. Хоружого, «що істота «Людина» відчуває сильні зміни, які зачіпають саму ії природу - i зачіпають так глибоко, що є потреба у перегляді та переосмисленні самого поняття «людської природи» [7]. Однак, автор зазначає, що у сучасній науці як ситуація в цілому, так окремі визначальні явища і процеси «не отримали ще ґрунтовної концептуалізації». Гострота проблеми розуміння людини і перспектив ї̈ розвитку передбачає виділення та дослідження таких структур, які спрямовують «провідні антропологічні тренди». Однак, сьогоднішня антропологічна ситуація головними сферами антропологічних змін визначає генотехнології i віртуальні практики та спрямовує орієнтир антропологічного розвитку постлюдина.

У контексті трансформативної антропології, постлюдина розглядається не черговим, а останнім (на сьогодні), як справедливо зазначає С.Хоружий, епізодом в еволюції антропологічних практик і 
теорій. Підкреслюючи вагомість трансформацій, що зачіпають фрундаментальні засади людської природи, автор розглядає види постлюдини. Кіборг - $€$ першим видом, поява якого зумовлена стратегіями з'єднання і зрощення людини з комп'ютерною технікою. Подальша інклюзія генотехнологій в антропологію виявляє можливості практичного маніпулювання генетичною програмою, геномом людини. За умови перевищення критичної частки генетичного матеріалу людини генетичними змінами, відбувається трансформація людини на основі кардинадьної зміни істотних властивостей живого організму. Щодо таких істот використовується досить адекватний термін Мутанти - це другий вид постлюдини, зумовлений розвитком генотехнологій. Ці ж стратегії реалізують можливість третьої екзотичної істоти - Клона, яка $є$ точною генетичною копією людського організму. Клон - генетично нормальна людська істота однак, маючи характер «копії, а не оригіналу», він має низку глибоких антропологічних відмінностей. Отже, Кіборг, Мутант, Клон - три версії постлюдини, до кожної з яких ведуть певні антропо-технологічні практики, сьогодні вже активно розвиваються (хоча і не досягли фрінальних плодів), але пов'язані із ризиками і є викликом існуванню самої людини.

У цьому зв'язку виняткової значущості набуває психологічна наука та практика як основа для розроблення стратегії еволюційної трансформації людини - перманентного розвитку Особистості. Потенційно кожна людина $€$ універсально спроможною до розвитку. Особливості розвитку кожної людини залежать від безлічі обставин, зокрема, і від особистої мотивації та потенціалу самої людини, ії природних якостей і задатків, здібностей та соціальних умов.

Досліджуючи проблему занепаду культури у сучасному світі та аналізуючи деструктивні фрактори в суспільно-економічному і духовному житті великий європейський фрілософ гуманіст А. Швейцер 
писав: «Саме наше суспільство перестало визнавати за всіма людьми як такими людську цінність і людську гідність. Певна частина людства стала для нас людським матеріалом, речами .... Людські долі - це ряди цифрр, певний статистичний матеріал, не більше» [8, с. 51-52]. Ми стаємо свідками дії трагічного закону, підкреслює А. Швейцер, згідно з яким виграш в одному (зростання матеріальних досягнень суспільства) пов'язаний з втратою в іншому (втрата духовного сенсу і властивої людям індивідуальності). Обставинами, які пригнічують гідність сучасної людини на думку автора - постійний поспіх, характерний для нашого способу життя, інтенсифікація взаємного спілкування, спільної праці і спільного буття багатьох на обмеженому просторі, відчуження стосовно собі подібним, абсолютна індиферентність, нав'язані обмеження в діяльності, безлика поведінка, надмірна схильність сучасної людини до зовнішнього впливу, відмова від найневід'ємніших прав індивідуальності: мільйони індивідів відмовляються від права на мислення, власноруч надягнуте ярмо духовної несамостійності, і, в кінцевому рахунку, деградація до зречення від істинно людських відносин навіть там, де вони можливі і доречні. Таким чином, унеможливлюється втілення потенційної здатності до розвитку особистості, оскільки, ідея розвитку особистості як мети ії життєдіяльності з необхідністю пов'язана з такою максимою як гідність.

Метою статті $€$ аналіз науково-теоретичного підґрунтя розроблення проблеми розвитку гідності особистості як основи еволюційної трансформації людини.

Виклад основного матеріалу. Аналіз змісту поняття «гідність» як етичної категорії засвідчує її основне значення у безумовній цінності людини на основі ії людської природи. В якості критеріїв гідності на різних історичних етапах застосовувалися такі об'єктивні параметри як: фрізичні якості індивіда, суспільне становище людини, рівень ії 
матеріального добробуту, суспільно-корисна праця, сукупність ї̈ громадянських прав і свобод. Не менша значущість надавалась суб'єктивним параметрам: рівню моральності людини, їі свободі і незалежності (у тому числі незалежності суджень), рівню розвитку ії особистісної відповідальності, якості вольових компонентів, а також здатності до самовизначення та самореалізації. За умови усвідомлення власної гідності особистість спроможність розвивати та реалізувати свій унікальний потенціал у вільній життєтворчості.

Гідність $€$ внутрішньою іманентною якістю людини. У семантиці поняття «гідність» містяться кілька значень: по-перше, позитивне вимір, що належить як об'єкту, події (номінал монети, товару, гідну працю, гідну винагороду), так і суб'єкту; по-друге, усвідомлення власної цінності - «бути до чогось здатним, кращим, чудовим», по-третє, статус людини, іï суспільна значущість, тобто ціна, яку їй визначає суспільство. Поняття гідності полісемантичне та використовується для підкреслення цінності, доброчесності, переваги, а також користі, ціни, вартості. В основі «Я-концепції» особистості знаходиться «базисна гідність», що розуміється як невід'ємна, невідчужувана властивість кожної особистості, яка виступає підставою універсальності її потреб та прав. Гідність розглядається як складне інтегративне особистісне утворення, що забезпечує саморозвиток людини і послідовне досягнення нею значущих результатів у соціальній сфрері, сфері інтелектуальних досягнень, а також зоні особистісного і духовного розвитку.

Розвиток особистості традиційно розглядають через аналіз динамічної системи міжособистісних і суспільних відносин, яку визначає взаємодія двох внутрішніх тенденцій психіки - тенденція до збереження i тенденція до зміни. Тенденція до збереження, орієнтована на відтворення набутого первинного досвіду, забезпечує 
регуляцію напруги, стабілізацію динамічної рівноваги психіки у процесі іiї еволюції. Тенденція мінливості орієнтована на порушення стабільності, сприяє появі у системі психіки різнорідних новоутворень, що і визначає розвиток системи. На основі взаємодії цих тенденцій особистість реалізує в соціальному середовищі різні утилітарні функціональні якості, за рахунок яких здійснюється динамічнорегулятивна діяльність.

У психоаналітичній теорії розвиток особистості 3. Фрейд розглядає як поступове формування особливої інстанції - «Над-Я» - вищої складової психічної структури особистості на основі первинних: «Я» і «Воно» [5]. Ід - «Воно» - визначають несвідомі потяги, лібідо, інстинкти, базові потреби, задоволення яких закладене від народження. Его - «Я» - утворене змістом усвідомлення на певному етапі розвитку своєї реальної суті. Супер-его - «Над-Я» - містить в собі правила поведінки, норми моралі, традиції, цінності, які особистість інтроектує в процесі соціалізації та керується у своєму житті. «Над-Я» генетично більш пізнє утворенням в психіці дитини, виконує функції внутрішнього цензора, самоконтролю, совісті, змушує коритися суспільним законам, регламентувати свою поведінку. На переконання 3. Фрейда структура «Над-Я» поступово виокремлюється і ніби надбудовується над структурою «Я», а згодом набуває над нею контроль і владу. «Над-Я» розуміється «як специфічний, віддифереційований всередині «Я» структурний осад, що виник в якості окремого утворення» [9, с. 261] у результаті відмови від «принципу задоволення» на користь «принципу реальності» [6]. Засвоєння соціальних, моральних норм дитини пов'язане 3 пригніченням заборонених потягів «Воно» $\mathrm{i}$ «» на користь наслідування або ідентифікації з моральними нормами, установками, цінностями, які сповідують батьки та суспільство загалом. 
«Над-Я» поступово поповнюється змістом зовнішніх батьківських вимог щодо дотримання моральних норм і стає інтрапсихічною вимогою дитини до самої себе. Базовою функцією «Над-Я», на думку 3. Фрейда, є встановлення внутрішньопсихічної і міжособистісної гармонії та здійснення соціальної адаптації, а також самоконтроль і самокритика. Функції «Над-Я» простежуються через думки, емоції, франтазії і почуття стосовно чогось. Емоції та афректи виконують сигнальну функцію. У випадку тиску з боку інстанції «Воно» та нехтування «принципом реальності», виникає покарання з боку «НадЯ» у вигляді почуттів сорому, провини, моральної тривоги або страху.

Таким чином, результатом морального розвитку особистості у класичному психоаналізі є формування структури «Над-Я» з функцією самопокарання за вчинки, що виходять за рамки моральних норм і ідеалів.

Проблема розвитку розроблялася у когнітивній психології у контексті проблеми моральної свідомості. Ж. Піаже [4] дослідив особливості розвитку і фрункціонування моральної свідомості у взаємозв'язку з поетапним формуванням пізнавальних здібностей дитини. Інтелект розглядався Ж. Піаже як когнітивний аспект поведінки, що структурує відносини між суб'єктом і оточенням. Інтелектуальне зізрівання дослідник вважає визначеним вимогами адаптації і організації. Адаптацію до вимог зовнішнього оточення дослідник розглядав як взаємодію двох урівноважених процесів: асиміляції (засвоєння зовнішнього досвіду і його трансформацію в уявні чи інтелектуальні продукти) і акомодації (пристосування уявних структур до нових аспектів уявного оточення). Важливим $є$ виокремлений другий принцип інтелектуального зростання - організація - як структурування, ускладнення та інтеграція розуму. Згідно із Ж. Піаже, знання є дією (схемою поведінки). У результаті розвитку ці схеми поетапно 
інтеріоризуються. Таким чином, відбувається не тільки відтворення об'єкта, а й сам суб'єкт постійно змінюється через пізнавальну діяльність. Однак, не всяке знання, отримане з навколишнього середовища, може бути асимільоване, а лише те, яке співзвучне внутрішнім уявним структурам суб'єкта. Такі когнітивні структури складають моральну свідомість дитини. На думку Ж. Піаже, етика являє собою систему правил, що діють в певній суспільній фрормації, а єдиним джерелом моралі може служити схвалення з боку суспільства.

Ґрунтуючись на положеннях теорії Ж. Піаже, Л. Кольберг [12] підкреслював основну роль когнітивних структур в моральному розвитку. Він розробив «когнітивно-еволюційну теорію моралізації» і виділив три рівні морального розвитку. Згідно із Л. Кольбергом, рівень інтелектуального розвитку $\epsilon$ необхідною умовою для розвитку відповідного рівня моральної свідомості, однак, не може вважатися достатньою. Так само, як і Ж. Піаже, Л. Кольберг вказував на соціальну детермінацію моральності. Він вважав, що розвиток моральної свідомості відбувається впродовж усього життя людини і не залежить від релігійних, національних і статусних відмінностей.

Вивчаючи закономірності морального розвитку, Л. Кольберг [12] виділив три рівні розвитку моральних суджень, які, в свою чергу, поділяються на дві стадії. Перший рівень Л. Кольберг позначає як доконвенціональний (доморальний) і розділяє на дві стадії: стадію «гетерономної» моралі і стадію індивідуалізму, інструментальної мети і обміну. Даний рівень притаманний дітям до 9-річного віку, а також підліткам 3 антисоціальною поведінкою. На стадії «гетерономної» моралі наявна орієнтація на покарання, і, як наслідок, основний мотив це уникнення порушення правил, яке призводить до покарання. На стадії індивідуалізму, інструментальної мети і обміну дотримання 
правил відбувається тільки тоді, коли це відповідає власним інтересам особистості.

Наступний рівень - конвенціональний (традиційний, етика відповідності загальноприйнятим нормам) - поділяється відповідно на третю і четверту стадії: стадію взаємного міжособистісного очікування і міжособистісного підпорядкування (етика хорошої людини) і стадію соціальної системи і совісті (етика підтримки влади). На стадії взаємного міжособистісного очікування і міжособистісного підпорядкування основним мотивом $€$ уникнення несхвалення оточуючих, потреба бути хорошою людиною у власних очах і очах суспільства. Четверта стадія - соціальна система і совість (етика підтримки влади) - характеризується виконанням обов'язків, з якими людина згідна. Основний мотив - зберігати життя і уникати руйнування системи, підтримувати закон і громадський порядок і турбуватися про інтереси суспільства.

Третій рівень - постконвенціональний (етика самостійно вироблених моральних принципів) - досягають, на думку Л. Кольберга, тільки після 20 років, однак, не всі дорослі люди. На цьому рівні виявляється здатність до самостійного вибору, індивідуальної моральної відповідальності і загальної зрілості особистості. Постконвенціональний рівень поділяється на: стадію соціального договору або корисності і індивідуальних прав (етика демократично сприйнятих законів) і стадію універсальних етичних принципів (етика індивідуальних принципів поведінки). На стадії соціального договору усвідомлюється існування безлічі цінностей і думок та їх відповідність загальнолюдським цінностям. Основний мотив - завоювання поваги іншої людини чи суспільства загалом. На стадії універсальних етичних принципів реалізується можливість життєдіяльності на основі самостійно обраних принципів. 
Теоретична модель Дж. Левінджер [13] продовжує традицію виділення послідовних стадій розвитку особистості, однак без прив'язки до її хронологічного віку. Дослідниця зауважує, що виділені стадії задають чітку логіку розвитку й структурують особистість, відображаючи рівень ії зрілості та орієнтовані на досягнення інтегрованої стадії. Дж. Левінджер зіставляє зміст цієї стадії із відомим описом самоактуалізованих особистостей згідно із А. Маслоу [1, 2]: повне прийняття і схвалення реальності й комфортна взаємодія із нею; схвалення інших і себе ("Я роблю своє, а ти - своє. Я в цьому світі не для того, щоб відповідати твоїм очікуванням. І ти в цьому світі не для того, щоб відповідати моїм очікуванням. Я $€$ я, ти $€$ ти. Я поважаю і приймаю тебе таким, яким ти є"); захоплення улюбленою справою, орієнтація на завдання, на справу; автономність, незалежність від соціального середовища, самостійність думок; здатність до розуміння інших людей, увага, доброзичливість до людей; здатність до постійного оновлення досвіду, вражень; здатність до розрізнення мети і засобів, зла і добра (усвідомлення, що не будь-який засіб придатний для досягнення мети); спонтанність, природність поведінки; фрілософрське почуття гумору; саморозвиток, вияв здібностей, потенційних можливостей, самоактуалізуюча творчість у роботі, любові, житті; готовність до вирішення перспективних проблем, до усвідомлення та засвоєння власного досвіду, справжнього розуміння своїх можливостей. Безумовно, самоактуалізація $€$ перспективою еволюційного розвитку гідної особистості, унікальної та інноваційної, здатної до перманентного розвитку.

Заслуговує на увагу основна ідея теорії позитивної дезінтеграції К. Домбровського [11] щодо наявності у людини потенціалу безперервного розвитку - вона приречена на розвиток. Автор переконливо доводить, що процес безперервного становлення людини 
проходить через фрази (біологічні) та рівні (соціально-психологічні) і відбувається за рахунок внутрішніх тенденцій і динамізмів індивіда. Потенціал розвитку $є$ ресурсом постійного руху і змін особистості під впливом ієрархії внутрішніх ціннісних орієнтирів та цілеспрямованості.

Процес розвитку автор визначає механізмами позитивної дезінтеграції, яку розглядає відкритим процесом, що триває впродовж всього життя людини і не передбачає принципового завершення. Позитивна дезінтеграція простежується а в змінах, послабленні, порушенні вихідної єдності та злагодженості через порушення чи руйнацію зв'язків між компонентами структури або її розпад. Процесом позитивної дезінтеграції в онтогенезі визначені неврози, психоневрози, зовнішні (соціальні, міжособистісні) і внутрішні конфрлікти. Однак, процес позитивної дезінтеграції забезпечує динаміку особистісного становлення, зростання та розвитку.

На рівні вторинної інтеграції, як найвищому рівні розвитку, процес прогресуючого синтезу призводить до гармонійної єдності, яка $€$ функцією найбільш повного втілення ідеалу [11]. Аналізуючи зміст цього рівня, автор зазначає, що на цьому рівні вже немає внутрішніх конфрліктів - належне стає дійсним. Особистісний ідеал є основним і найбільш сильним динамізмом вторинної інтеграції. Особистість, на думку К. Домбровського, максимально характеризує цілісність, гармонійність, високий рівень саморефлексії, свідомості, здатність до самостійного свідомого та вільного вибору, переконаність в істинності власної позиції, у цінності власних цілей, усвідомлення незавершеності розвитку і потреби постійного самовдосконалення. Вершиною розвитку особистості є реалізація у життєдіяльності «особистісного ідеалу», основою якого К. Домбровський вважає такі норми і якості людей, які мають постійний характер, визнані і реалізовані людством ще на зорі його культури і які можна назвати безвідносними. Вони виявляються 
через історію людства, акумулюючись більшою чи меншою мірою у відомих історичних особистостях. Визначення дослідником «особистісного ідеалу» суголосне змісту поняття гідності особистості. Важливим $€$ також принципова настанова автора на незавершеність розвитку, незалежно від рівня досягнення ідеалу, та фраховий опис показників динаміки станів особистості на різних рівнях розвитку хоч він і має узагальнений характер.

Провідний експерт в сфері психології дорослого розвитку і теорії розвитку его S. Cook-Greuter [10] особливо змістовно розглядає динаміку різних способів надання смислу реальності або частковим ситуаціям. Евристично цінним для дослідження розвитку унікальної особистості $€$ емпірично обґрунтований опис можливого варіанту від несвідомого, недиференційованого симбіозу немовляти до свідомого переживання включеності у всесвіт зрілого дорослого - від дораціонального до метараціонального, від довербального невігластва (незнання) до зародження постсимволічної мудрості, коли людина усвідомлює природний взаємозв'язок усіх явищ і штучність кордонів, об'єктів, традиційної самоідентифікації й історій про життя та природу, стає вільною, відповідальною, творчою.

Висновки. Ґрунтуючись на сучасних наукових позиціях ми розглядаємо розвиток як особливий різновид внутрішніх змін, пов'язаних не лише з появою нових елементів, але із зміною структури та специфіки взаємозв'язків між ії елементами. У більшості теорій розвиток людини розглядають як рух по спіралі, який можливий у всіх напрямках. Спрямування вгору потенціал особистості набуває під впливом духовних цінностей на основі потреби в самоактуалізації та гідності особистості. «Вертикальний» розвиток передбачає прогресивні трансформації у структурі особистості, у ії життєдіяльності та в навколишньому просторі. Горизонтальний рух і зміни розглядають як 
експансію, тобто рухи-переміщення всередині однієї і тієї ж стадії (адаптація, пристосування, вироблення навичок, накопичення знань). Рух донизу зумовлює тимчасову або постійну регресію найчастіше у зв'язку із фріксацією на нереалізованій потребі попередніх етапів розвитку. У сучасних умовах простежується тенденція реалізації потенціалу розвитку людини у вигляді горизонтального розширення: оволодіння новими навичками, новими техніками та технологіями, новими способами організації знань. Однак, розвиток особистості, самоактуалізація передбачають фундаментальний статус гідності. Гідність визначає процес саморозвитку на основі активізації самопізнання, усвідомленої саморегуляції, мотивації підвищення власної активності і продуктивності, прагнення до самовизначення i самореалізації.

\section{תimepamypa:}

1. Маслоу А. Дальние пределы человеческой психики / А. Маслоу. СПб.: Евразия, 1997. - 430 с.

2. Маслоу А. Мотивация и личность / А. Маслоу. - СПб.: Питер, 2003. $-352 c$.

3. Пиаже Ж. Избранные психологические труды / Ж. Пиаже. - М.: Международная педагогическая академия, 1994. - 680 с.

4. Пиаже Ж. Речь и мышление ребенка / Ж. Пиаже. - М.: ПедагогикаПресc, 1994. - 528 c.

5. Фрейд 3. Психология бессознательного. - М.: Просвещение, 1990. $448 \mathrm{c.}$

6. Фрейд 3. По ту сторону принципа наслаждения: «Я» и «Оно» /

3. Фрейд // Избранное: в 2 кн. - М.: Московский рабочий, 1990. - Кн. 1. $-160 c$. 
7. Хоружий С. С. Проблема постчеловека, или трансформативная антропология глазами синергийной антропологии. Философрские науки. 2008. № 2. С. 10-31.

8. Швейцер А. Благоговение перед жизнью/ Пер. с нем. А. А.Гусейнова Изд.-о: М.: Прогресс: 1992. - 576 с.

9. Энциклопедия глубинной психологии. Т. ІІІ. Последователи Фрейда / Пер. с нем. - М., «Когито-Центр», МГМ, 2002. - 410 с.

10. Cook-Greuter S. R. Ego development: Nine levels of increasing embrace [Electronic resource] / S. R. Cook-Greuter. - Access mode: http://newpossibilitiesassociates.com/uploads/9_levels_of_increasing_embr ace_update_1_07.pdf.

11. Dambrowski K. Multilevelness and Positive Disintegration / K. Dambrowski. - New York: Dabor science, 1977. - 447 p.

12. Kohlberg L. Moral stages and moralization. - /L. Kohlberg. - New York: Winston, 1975. - $125 p$.

13. Loevinger J. Ego development: conceptions and theories / J. Loevinge. - San Francisco: Jossey Bass Publishers, 1976. - 504 p.

\section{References:}

1. Maslou A. Dalniye predely chelovecheskoy psikhiki / A. Maslou. - SPb.: Evraziya. 1997. - $430 \mathrm{~s}$.

2. Maslou A. Motivatsiya i lichnost / A. Maslou. - SPb.: Piter. 2003. - 352 s.

3. Piazhe Zh. Izbrannyye psikhologicheskiye trudy / Zh. Piazhe. - M.: Mezhdunarodnaya pedagogicheskaya akademiya. 1994. - $680 \mathrm{~s}$.

4. Piazhe Zh. Rech i myshleniye rebenka / Zh. Piazhe. - M.: PedagogikaPress. 1994. - 528 s.

5. Freyd 3. Psikhologiya bessoznatelnogo. - M.: Prosveshcheniye. 1990. $448 \mathrm{~s}$.

6. Freyd Z. Po tu storonu printsipa naslazhdeniya: «Ya» $i$ «Ono» / Z. Freyd // Izbrannoye : v 2 kn. - M.: Moskovskiy rabochiy. 1990. - Kn. 1. - 160 s. 
7. Khoruzhiy S. S. Problema postcheloveka. ili transformativnaya antropologiya glazami sinergiynoy antropologii. Filosofskiye nauki. 2008. № 2. S. $10-31$.

8. Shveytser A. Blagogoveniye pered zhiznyu /Per. s nem. A. A.Guseynova Izd.-o: M.: Progress: 1992. - 576 s.

9. Entsiklopediya glubinnoy psikhologii. T. III. Posledovateli Freyda / Per. s nem. - M. «Kogito-Tsentr». MGM. 2002. - 410 s.

10. Cook-Greuter S. R. Ego development: Nine levels of increasing embrace [Electronic resource] / S. R. Cook-Greuter. - Access mode: http://newpossibilitiesassociates.com/uploads/9_levels_of_increasing_embr ace_update_1_07.pdf.

11. Dambrowski K. Multilevelness and Positive Disintegration / K. Dambrowski. - New York: Dabor science, 1977. - 447 p.

12. Kohlberg L. Moral stages and moralization. - /L. Kohlberg. - New York: Winston, 1975. - $125 p$.

13. Loevinger J. Ego development: conceptions and theories / J. Loevinge. - San Francisco: Jossey Bass Publishers, 1976. - 504 p. 